This item was submitted to Loughborough's Research Repository by the author.

Items in Figshare are protected by copyright, with all rights reserved, unless otherwise indicated.

\title{
Introduction: Shakespeare's public spheres
}

PLEASE CITE THE PUBLISHED VERSION

https://doi.org/10.1080/17450918.2018.1439093

\section{PUBLISHER}

Taylor \& Francis @ Nigel Wood

\section{VERSION}

AM (Accepted Manuscript)

\section{PUBLISHER STATEMENT}

This is an Accepted Manuscript of an article published by Taylor \& Francis in Shakespeare on 15 March 2018, available online: http://www.tandfonline.com/10.1080/17450918.2018.1439093.

\section{LICENCE}

CC BY-NC-ND 4.0

\section{REPOSITORY RECORD}

Wood, Nigel. 2019. “Introduction: Shakespeare's Public Spheres”. figshare. https://hdl.handle.net/2134/38354. 
Introduction - Shakespeare's Public Spheres - Nigel Wood

(n.p.wood@lboro.ac.uk) - Loughborough University

Keywords: Habermas, Public Sphere, Shakespeare, Twelfth Night, Reader Response criticism, Performance.

Abstract: Habermas's sense of a "cultural Public Sphere" is a notoriously complex term, and, when applied to Early Modern cultures, needs careful definition. This essay both introduces the variety of methods by which we might approach playtexts with a view to their public - auditory - impact and contributes to a debate about an audience's understanding of Shakespeare's plays. By selecting two words and their spread of use in one play, Twelfth Night, we might appreciate the potential for meaningful ambiguity latent in how we hear the language of live performance, If we search for how certain terms (in this case, the cluster of semes derived from repetitions of "fancy" and "play"), we might find at times incompatible senses, yet we get near to appreciating the range of Early Modern dramatic language.

The contributors to this collection reflect on issues that cannot always be safely separated into "criticism" or "performance" sections, as any reflection on the public status of a playtext relies on contexts (audiences then) and pretexts (any scribal assumption as to how the words may now be heard) that persist today albeit in significantly alternative forms in decisions to be made by any interpreter. Any divide between study and rehearsal-room is not, indeed, a modern distinction; as Cyndia Susan Clegg has recently noted, the experiences of "reading clusters" where the earliest dramatic texts were concerned, were significantly distinct from that of their first auditors (18-21, 120-79). Reading habits fed into an auditory "public imagination", but were still distinct (154-56, 180-82). This is to recognise the experiences of a sufficiently literate audience as of paramount significance - and whether the text catered for them principally. Alternatively, one's approach to the verbal texture of any drama should allow for radical surprise, the provision of shock and less rehearsed effects that elude immediate categorisation. It is therefore one qualitative test of how any playtext survives that its potential for public performance alters and prompts reformed alliances with new audiences. That is why our own senses of "audience" and/or "play" need analysis as the content of these terms has recently undergone a material shift into electronic and hidden forms of manipulation, where complexes of non-literary as well as theatrical effects supply implicit conventions of seeing and participation.

These essays share a concern with how audiences might attain meanings, always keeping in view the crucial distinction between our "Public" and "Private" selves. What happened then when we witnessed the action unfold - and what are the options now that are to some degree pre-formed and conventional. This is thus an 
important formative step towards identifying - and appreciating - the challenge of live theatre: its vocative confrontations and its localised complexity. The staple ingredient of how drama survives is verbal, but that opens rather than closes interpretative options. For Shakespeare's first audiences, certain keywords or phrases were heard - and thus understood - in subtly modified ways in the playhouse and therefore signified via distinctive cognitive processes. ${ }^{1}$ This normally lies outside the brief for even the most minute investigations that editors regard as their task. We expect the annotation in the best editions to perform the task of restoring meaning to words or phrases that had impact in first performances, yet this recovery work - piecemeal and inevitably localised - rarely takes full account of the relay of semes that gather force in live performance and that assume crucial significance for particular audiences. The word choice might illustrate an attempt at a valency of meanings, the ambiguity of which shapes an understanding not by reference to precise definition but rather by how an action gives rise to a gathering of shades and echoes. For example, Orsino would seem to have concluded the action of Twelfth Night (Feste's coda is a surprise, of course) by drawing our attention to Cesario/Viola's male attire:

Meantime, sweet sister,

We will not part from hence. Cesario, come -

For so you shall be while you are a man,

But when in other habits you are seen,

Orsino's mistress, and his fancy's queen. (5.1.381-5)

The strangeness of the appellation "fancy's queen" is not frequently noted; indeed, in Elizabeth Donno's Cambridge edition, "fancy" is rendered as merely "love", with the encouragement to return to two previous uses at 1.1.14 and 2.4.31 (Donno, 1985: 149), ${ }^{2}$ yet these instances open up rather complex possibilities: when Orsino ruminates on the debit side of love in his opening lyric, it is by associating the emotion with a perverse protean quality - "So full of shapes is fancy./That it alone is high fantastical" (1.1.14-15). Likened to the sea, "fancy" nullifies "validity and pitch" (1.1.12). . ${ }^{3}$ In II.iv., Orsino, thinking he is addressing the boy, Cesario, confesses that male "fancies"

\footnotetext{
${ }^{1}$ See especially Munro, Speaking History. This is extended to more holistic approaches to literary composition in Munro, "Archaic Style". Also, Lamb where his premise as to how the "perlocutionary" effects (following Austin's line) of the texts are not perfectly aligned with any intended - "dictionary" conditions (202-8).

${ }^{2}$ Bruce R. Smith in his edition glosses this as "love" (110). Lothian and Craik in their Arden edition are more expansive: "The word 'fancy' is here used with no derogatory sense, but is synonymous with "love'" (153). Warren and Wells do not supply any gloss at all (220).

${ }^{3}$ It is perhaps worth exploring the approach towards Orsino in this first scene that allows a rather more serious role for him than just love-sick fool, given the sentiments - consistent throughout the play - that he voices here.
} 
are more giddy and unfirm,

More longing, wavering, sooner lost than worn,

Than women's are.

The relevant footnotes for both these previous occurences take fancy to be love of some sort $(46,82)$. It would be reassuring to come to rest after the comic complications of the play on a foundation of true and unmistakable emotion: to be "fancy's queen" might an unalloyed compliment if it were not for those earlier associations that Orsino has unambiguously introduced. Moreover, the word is also used in the play in other narrative contexts: it is how Malvolio imagines Olivia might regard him were she to require a partner: "Tis but fortune; all is fortune. Maria once told me she did affect me, and I have heard herself come thus near, that should she fancy, it should be one of my complexion" (2.4.22-24). Even less reassuring is Sebastian's consternation at Olivia's unexpected rush of emotion for him that seems like madness: "Let fancy still my sense in Lethe steep;/ If it be thus to dream, still let me sleep!" (4.1.61-62). Donno does admit, in this last example, that a sense of simple "love" is not sufficient and in her annotation to the passage, she concedes that "fancy" might here veer towards "Imagination" (125).

There is thus a proposition that is worth some extending to any public, performative, understanding of the repetition of "fancy" or its derivatives: in the instant of hearing and uttering, any nice differentiation between the possible shades of meaning met in the one word or phrase is rarely possible. Consequently, a thematic punning amounting to a fruitful ambiguity is always available, and, if possible, then it is potentially motivated and is thus to be regarded as interpretative material.

If we were to regard the choice of "fancy" in these instances to be carefully considered and therefore open to an ingenuity of interpretation, then any sense of "love" is crowded out by competing foci. Indeed, the primary sense of the word in the $O E D$ is not as Donno would have it mean: from a spectrum comprising "fantasy" from scholastic psychology (meaning $1 \mathrm{~A}$ ) to "3. Delusive imagination; hallucination" to "6. A supposition resting on no solid grounds; an arbitrary notion" to "7. a. Caprice, changeful mood " to "8. a. Capricious or arbitrary preference", "love" is the very least of the semes that accrue to the word. Perhaps 4. a. which introduces a more recent possibility, nearer to associations of the creative imagination, might also be involved: "the process, and the faculty, of forming mental representations of things not present to the senses; chiefly applied to the so-called creative or productive imagination, which frames images of objects, events, or conditions that have not occurred in actual experience". It is therefore not extraneous or to be over-ingenious to explore just how Orsino regards Cesario/Viola and the possibility that their future lives might potentially be chimerical; he has to imagine how Viola will in fact be - free of disguise or the novelty of surface attraction - and the play's narrative impetus is not promising, 
as Orsino is all too aware of fancy's delusive qualities as is Sebastian and the audience who judges Malvolio's imagination, fed by Maria, as mistaken and errant.

It might be possible to segregate Orsino's final gesture towards "fancy" from earlier instances, yet in a first aural acquaintance a more cerebral perspective, where we eventually dissociate certain voicings from others and isolate certain semantic nuances as the really crucial and intended ones, is not easy to maintain hermeneutically. In attempting to rescue these playtexts as public documents, such details matter. Whilst this is recognised in some editions, in others it is not. For example, Lothian and Craik extend a concept of "love" with reference to Orsino's apparently self-indulgent luxuriating in ideal love; the "abatement and low price" (1.1.13) that love is apt to undergo, "even in a minute!" (1.1.14), points to its identification as "fancy", and a link to Theseus's identification of the lover with the poet and lunatic from Midsummer Night's Dream (5.1.7-8) and Berowne's perspective on love's "parti-coloured presence", full of polymorphous shapes and forms, that assail the lover with ridicule (Love's Labour's Lost, 5.2 .759 - (6). ${ }^{4}$ Consequently, it would follow, if this is recognised, that "love" is an inadequate reading of "fancy" in all of its instances in the play - derived from that first iteration in Orsino's opening speech and not terminated there. ${ }^{5}$

There is a wider interpretational issue here that carries over into other Shakespeare texts; the exploitation of a full spectrum of available meanings is at the essence of drama and, minus a regulatory linguistic framework, the essence of Early Modern wit and exploratory rhetoric. However we have Viola/Cesario and Orsino leave the stage, it is incumbent on us to recognise how directed the context for that exit might have been, and however narrowly or expansive one's definition of "love" at this point might be, the simplest sense of the term proves an inexact rendering of the linguistic potential at this point in the action. "Fancy" is indeed an elusive term but at the same time a rather telling one, too, for its associative power leads one to an exact gesture of trepidation and excitement, of loss of bearings and a discovery of others, that is deftly introduced at a significant episode. At the same time as there is a trace of necessary judgement and human sympathy, there remains a trace of unmoored contingency. Aside from Twelfth Night, this one word incorporates the basic need to suspend any audience's inclination towards rational calculation. The Chorus from Henry $V$ bases its appeal to the play's auditors on an activation of "fancy", whereby we might "play" with this impulse so as to envisage the English

\footnotetext{
4 See also the Ovidian legacy of this trope in White 14-44, Rudd especially 122-25; Stavig 255-81, and Bate 130-46.

${ }^{5}$ It is worth noting Keir Elam's attempt, in his Arden edition, at adopting this complexity throughout, yet his gloss of 1.1.14, associates "fancy" with a particularly narrow understanding of "love" (162) derived from the tradition firmly established by Onions, 1986. The accrued emphases that might appear congruent yet actually signal divergent nuances from "fancy" - towards imaginative perception or, alternatively, delusion - cannot be erased afresh once the word is repeated; his gloss on "fancy's queen", "ruler of his desires" (352), is a rather pre-emptive judgement, denying any potential of continued misperception on Orsino's behalf - at least until Cesario assumes her/his proper garb as Viola - and possibly thereafter.
} 
fleet's "silken streamers" and the "ship-boys" clambering up "hempen tackle" (III.0.78). Gower hushes an audience for Pericles by encouraging attention to fine detail, whereby "fine fancies" might piece out the brevity of dumb show and other obliquities (Sc. 10.13), and who would begrudge Yorick the compliment of being possessed of "infinite jest" and "most excellent fancy" (V.i.181)? Turn the dial just a little and one cannot overlook the dismissal of the baseless notions that Goneril annexes to the word (I.iv.304) or our first encounter with Don Armado as a "child of fancy" caught up in "high-born words" (Love's Labour's Lost, I.i.168, 170).

The more interesting test-cases in performance are more to do with intermediate senses that cannot be easily interpreted as wholly positive or wholly pejorative. Take Enobarbus's rapt cameo description of Antony encountering Cleopatra for the first time: the beggaring of "all description" involves us imaging how "fancy" might "outwork nature" (II.ii.205, 208) in any portrait of Venus, a trope taken up later in the action when Cleopatra, "past the size of dreaming", concludes that "nature wants stuff/To vie strange forms with fancy" as she grieves for the loss of Antony who stands in her imagination as "nature's piece against fancy" $(5.2 .96,96-97,98)$. It is not a case of an audience weighing the accuracy of Cleopatra's perspective, as if any actor might fulfil the appellation onstage; it is rather a case of registering the tragic requirement to "outwork" base reality and whether the couple do indeed portray to us "immortal longings" (5.2.276) - or were ever meant to. The same might be evident in Helen's distress at Bertram's remove, feeding her "idolatrous fancy" that leads her to "sanctiy[ing] his reliques" (1.1.96-97), or Troilus's association of "purity" with a love of Cressida that has so angered the "blest gods" that his fancy might indeed be punished $(4.5 .23,24)$. We might, however, wish to add to any interpretation of such "purity" the reflection that Troilus retains a faith in the integrity of his love at the point at which he might have concluded that it was misplaced, overhearing Diomedes's apparently successful overtures to Cressida, a devotion engaging "so eternal and fix'd a soul" with his "fancy" (5.2.168-69). Lastly, deliberating on his fateful choice of the caskets, Bassanio hears the accents of fancy in an accompanying song, that poses the question as to the source of its intuitions, either in the head or heart, or "engender'd in the eyes" alone. In ringing "fancy's knell" $(3,2.63-70)$ just before that choice, we might consider whether there has been enough evidence to perceive the growth of a more rational, unfanciful, Bassanio in place of the callow lover or not.

These interpretational cruces only appear insoluble if we approach them expecting decisive and unitary comprehension. What is uncovered by dwelling on these details are multivalent lexes that - then as now - achieve a form of symbolism: it might be worth starting from the assumption that Orsino is as deluded in love at the play's end as he appears to be at the start, that Helen loves Bertram too well (idolatrously, perhaps), that Cleopatra and Antony gloriously fool themselves in their affections, and that Bassanio could be - for there is surely doubt - choosing the correct casket guided by emotional guess-work. 
In closing the action of Twelfth Night, Feste indeed ends our own roles as audience-members by declaring that "[his/the company's?] play is done" (V.i.406). The conventional nature of this leavetaking is perhaps in line with an appeal for approbation and applause. The striving to please an audience also involves the sobering realisation that the revels of make-believe are shortly to cease. The King becomes a "beggar" as he closes All's Well That Ends Well in order that all may be "well ended", a conclusion that derives from a play that is "done" (5.3.346). The identification of the reference to a stage play is obvious. Marston's Histrio-mastix (acted c. 1599; pub. 1610) indicates the Epilogue's role as requesting, through a "plaudite", the charity of the audience: "The glasse is run, our play is done,/Hence Time doth call, wee thanke you all” (9). Thomas Nashe's Will Summer in his Pleasant Comedie, called Summers Last Will and Testament (1600) becomes a herald of a much wider cessation, not only the event that has involved us all, but also an invasion of extra-theatrical consciousness consonant with Feste's disappearance from lives in general. Without the magic of art, actors are indeed beggars, and Summer associates this fact when his "play is done" with the harsh reality outside the theatrical charmed circle. Vertumnus introduces Solstitium - "like an Aged Hermit, carrying a payre of balances, with a houre-glasse in eyther of them" - to accompany him offstage (7). It is therefore not merely a theatrical convention that is offered by Feste but rather a more public concern about "play" in general.

Consulting the $O E D$, as expected, could suggest a conjunction here of the stage world with the activity of recreation (meanings III.16a with $6 \mathrm{a} / \mathrm{b}$ ), yet there is available a greater depth in the reference - to jesting (8a) and also 13a, involving absence from work. Specific to a sense of possible irresponsibility in spectating is this choice of "play", the sense of a return more normally symbolised by the very title. Moreover, "play" is very much part of the weave of this particular play: from Viola's "I am not that I play" (1.5.179) to the indulgence in play of Sir Toby at "traytrip" and "cherry-pit with Satan"(2.5.179; 3.4.112)) plus Feste's willingness to "play" "Lord Pandarus" (3.1.50). These more incidental voicings might be taken as non-thematic, yet the plot's events throw up aspects of "play" that emphasise and develop these repetitions. Most metatheatrical might be Fabian's comment on Malvolio's depth of deception, that "If this were played upon a stage" it would be heard as "an improbable fiction" (3.4.122-23), but, symphonically, it refers us back to the first line, Orsino's desire that the playing of sweet music might be "the food of love" (1.1.1). In the end is a sense of a beginning.

Thus it is that any compilation of a glossary of terms used by Shakespeare and his contemporaries is always in danger of grossly simplifying the various dramatic situations from which their items are culled. Moreover, once we place these keywords in any sphere of public parlance, we complicate even more the semantic possibilities in that the most ambiguous terms reach out to areas of cognition that might be fleeting and transitory and that cannot be easily decoded out of an immediate context, where the colours of language indicate sub-meanings that 
emerge and recede over short passages of time but that were part of the mix for first performance audiences. It is also specifically the public resonance of this fruitful mix of semes that is worth noting; not that any Globe audience now approximates to the relative impoliteness of such assemblies then, but rather that there were and are liberties presented in a crowd that do not as readily appear in a private contemplation. As Hannah Arendt asserted, the private sphere of dependency and survival where the political is registered but not challenged is - when one perceives communally - replaced by a capacity for transformation and radical revaluation, a potential for action (116). ${ }^{6}$ For every fear that the crowd might become the mob (evident, for example, in the murder of Cinna the poet in Julius Caesar [3.3]), there is also their steadfast potential to be choric manipulators themselves (see the citizens in Richard III, 2.3). Entering any sense of the Public Sphere could then (as now) be a commitment to a form of action, sometimes implicit and sometimes not.

The term, "Public Sphere", has become a common one in academic discourse and consequently it has proved capable of varied definitions and of sometimes alternative associations. At its most basic, one might approach it as a consideration of meanings that are created - or that come into being - once any statement is made public. What pre-existent associations might it attract, and what (by now) hidden values did the writer anticipate would be current once any audience was in mind? This had its foundations, as far as the Elizabethan public theatres were concerned, in a rapidly developing sense of "audience" and an awareness of the "public" self, a belief that humans, by dint of personal effort, were able to improve themselves. The most available factor in this self-help is more usually taken to be individual study and personal accountability - otherwise, Faustus's tragedy lacks an important ingredient; if the "studious artisan" $(\mathrm{sc} .1,55)$ were predestined to damnation then his books - to say nothing of Prospero's - are simply snares. Biblical lore might allow no human intervention and providential truths are ungainsayable. Yet solitary improvement - the precarious assurance of the exile - is not the only means. In Francis Bacon's The Twoo Bookes of Francis Bacon. Of the proficence and advancement of Learning, divine and humane (1605), it is in "Civile affaires" that, equivalent to the pacified beasts and birds subdued by Orpheus, humans found their best selves, and where "the proper naturall appetites of Prey, of Game, of Quarrell" might be held at bay and we might be "stood all sociably and lovingly together" (I.vii.2, 49). Eloquence is an obligation for silence or reserve will allow - by default - the basest instincts to emerge. It is preeminently the performative qualities that enforce virtue or good sense, where the world is brought "upon the stage"; prone to abuse though this is, the Ancients considered it "the Archet, or musicall Bow of the Mind" and a fact that "the minds of men are more patent to affections, and impressions, Congregate, than solitary" (II.xi.2). Even those antagonistic to the theatre, were agreed on its potency for attracting attention; Stephen Gosson's perspective on the "publike Theaters" was one that regarded an

${ }^{6}$ See also Judith Butler's gloss on this distinction between the Private and Public spheres (44-48). 
audience as anything but negligent in attention, gazing at "any notable shew" by standing "upright with delight and eagerness to view it" (C7v). The forum for assessing public drama is thus determined by how audiences were accustomed to regard such displays and also how they encountered specific forms of language. Assuming that Orsino's view of Viola-as-Cesario might tally with an audience's and that she can become "fancy's queen", one might find that the more likely cognition involves a hybrid of overlapping emphases, where Orsino is more taken by an imaginative vision of his beloved than any memory (inevitably) of her as a woman, and where the distinct possibility of misprision is entertained.

Coming to terms with an Early Modern Public Sphere is not an easy task, for the term in modern parlance is derived from Jürgen Habermas's sense of it in his The Structural Transformation of the Public Sphere and this is filtered through assumptions derived from his preoccupation with Enlightenment possibilities, wherein the force of public opinion could be strengthened by the suddenly easier processes of dissemination that emerged in the eighteenth century aside from direct Court or governmental control. By a recursive irony, however, this awareness of relative public freedom could actually be inflected by forms of market exchange and thus - ultimately - private self-determination (141-51). Tantalisingly, Habermas focussed much more on what he termed the "political " public sphere than he did on its counterpart, the "cultural" phenomenon of performance and representation. One may feel free, therefore, to be Habermasian when dwelling on Shakespeare's public impact rather than a strict adherent.

It is therefore fruitless to identify any one social forum or norm that suffices through time, for such Public resources (such as coffee-houses, a free press or unlicensed performance) eventually attract commercial or authoritarian influences. Any public freedom is the more valuable for its tenuous and temporary hold on material and spiritual forces. For Early Modern researchers and performance theorists, therefore, this moving target still retains some significance, for it is a vital ingredient in artistic freedoms and also accountability in its capacity to reach out to public concerns. We cannot always locate it locally and physically for a sense of being a "Public" is excitingly in process whenever we inspect the evidence for "a" Shakespearean audience and an auditorium only partially causative: as Lena Cowen Orlin and both Peter Lake and Steven Pincus have noted (Orlin 109-22; Lake and Pincus 1-30) display entails a move not only towards reification but also public inspection. The "Private Sphere", the student and her/his books, involves a form of response radically alternative to an audience's reactions that emerges from impulse and instant recognition.

Drama is a physical representation in duration; this is worth re-stating, for there is a temptation to freeze the frame and regard play action as some sort of "Icon". ${ }^{7}$ As a

\footnotetext{
${ }^{7}$ I here adopt the sense of an artistic Icon from Wimsatt/Beardsley (xvi-xvii): "At the fully cognitive level of appreciation we unite in our own minds both speaker and audience. This principle, though it has to remain largely implicit in most rhetorical discussion, is actually that by which the various levels
} 
public spectacle, it is a form of rhetorical persuasion, where statements uttered by some characters, say, in the first act might be strategically countermanded or modified by subsequent gestures sometimes by the same characters. The proposal that any public event is memorable - or even significant - because it can be recognised as a pattern or pigeonholed according to prior categories runs up against a contrary impulse: salutary shock or surprise. Simpler forms of contextualisation tend to limit this power and domesticate the unexpected or the inconsistencies of dramatic conflict, and it presupposes some unity of angle or perspective on behalf of any audience: "the" spectator or "the" intended audience. As Yves Bonnefoy has it, a true poet does not wish for naïve proselytes: in lifting one's eyes from the page or admitting interruption of experience or distraction, self-aware play-going might be the goal aimed at, where one might be "open to [a] plentitude that descriptions and formulations cannot reach" (800). Indeed, the action is a provocative to a process of discovery, whereby there may be recognised what would normally have been left "unsaid". Thus, there is recognition, meanings that are publicly acknowledged, and then there is transgression, a breaking away from such communal acceptance. For Wolfgang Iser complex spectating is a matter of "double meaning", whereby "the spoken is constantly toppled by the unspoken and our awareness of a difference between the characters themselves and their language". Eventually, the only "finality" of any action is "pragmatic" (126): there has to be an ending of physical representation, but that is not to be confused with a finite quality imposed upon our thought processes or impulses.

In interpretative terms, the Public Sphere cannot perennially be "owned" by any one influential constituency as this instance is a reminder of the unpredictability of a genuinely dialogic interchange, where "languages" or discourses meet and get redirected. It is easier, but not exhaustive, now to excuse the deep study of a Shakespearean text as an exercise in discovering it as an organically unified achievement or as, ultimately and conversely, a record of deictic gestures to the transitory efflux of a particular culture.

It would also be an unwelcome abbreviation to regard theatrical experience in the Early Modern epoch confined just to the public stages: theatre, less traditionally defined, pre-dated the growth of secular drama and structured audience response. Bear-baiting, fairs and civic pageantry, for example, were staged events that created their own publics and possessed the potential for defining the dramatic in ways that do not always intersect with our own approaches to playtexts. London was in itself dramatic and its "Liberties" (wherein the Globe and Blackfriars operated) liminal spaces, and yet the city was understood in mental as well as legal categories: civic jurisdiction could be mapped but marginal transgressions could only be described

of the poem's meaning are integrated". If we are to "lay hold of the poetic act to comprehend and evaluate it, as a critical object, it must be hypostasized". My concern is that this visits undue consistency of purpose and form on the blueprint for a dramatic event. 
after the event, as effect rather than prescribed and anticipated release. ${ }^{8}$ In Habermas's later understanding of a Public Sphere, it provided a network of interests rather than a consistent location both spatially and culturally, a means by which information might be communicated and points of view debated and represented with a minimum of governmental or religious interference; it cannot be said to be powerful in functional political terms, yet, in a pre-democratic culture it could radiate influence and permeate - for a time- the thinking of a wide range of auditors (Between Facts and Norms 360-66), ${ }^{9}$ It could also be a significant factor in how any author regarded his literary/dramatic work.

That is why the theatre was distrusted and operated always within reach of censorship or closure. Pageants and church festivals might indeed commence with a ritualized format, yet the secular theatre rarely did. Theatre was in the weave of Elizabethan and Jacobean life and this "foreign country" possessed its own array of meanings and mythic impact. Monarchy, especially, was marked by staged appearances. Elizabeth I asserted that she - as all "Princes" - was "set on stages in the sight of all the world" (Holinshed IV:934) ${ }^{10}$, and James I made immense capital out of this trope when advising his son on viable kingship:

IT is a trew old saying, That a King is as one set on a stage, whose smallest actions and gestures, all the peoplle gazingly doe behold: and therefore although a King be neuer so precise in the discharging of his Office, the people, who seeth but the outward part, will euer iudge of the substance, by the circumstances; and according to the outward appearance, if his behauiour bee light or dissolute, will conceiue prae-occupied conceits of the Kings inward intention: which although with time, (the trier of all trewth,) it will euanish, by the euidence of the contrary effects, yet interim patitur iustus; and will, in the meane time, breed contempt, the mother of rebellion and disorder. And besides that, it is certaine, that all the indifferent actions and behauiour of a man, haue a certaine holding and dependance, either vpon vertue or vice, according as they are vsed or ruled: for there is not a middes betwixt them, no more then betwixt their rewards, heauen and hell. (James I and VI 79.). ${ }^{11}$

Majesty has to be manifest, not just possessed, yet the formulation allows for a disturbing gap between the "praeiudged conceits" of a first glance and any substance that had to be projected in the show of ritual. Time might indeed sift out the adventitious from the essential, but that is not the point here at issue. The public show exploited the will to believe and be believed. London itself offered dramatic potential, and any precision of focus on specifically theatrical spectacle needs to trace allusions that exceed the purely textual. Audiences at the Globe were

\footnotetext{
${ }^{8}$ See Mullaney 26-59; Dillon 79-95; Howard especially 1-28.

9 The debate as to just how "popular" the period's audiences might have been should be best approached via John Gordon Sweeney III (3-16); Annabel Patterson (32-51); Katherine Maus (12-34); Anthony B. Dawson and Paul Yachnin, (11-65).

${ }^{10}$ See in this regard, Greenblatt 21-65; Montrose 151-78; Reynold and Montrose, 1996a. 11 This trope has often been discussed in iconic terms, but its political vulnerability is noted by David Scott Kastan (109-47), and Richard Wilson (73-93).
} 
characterised from outside as a motley crew. George Whetstone, in his prefatory "Epistle" to one of the most direct sources for Measure for Measure, Promos and Cassandra (1578), was struck by the clash between "grave Counsels" and the "advise of fooles" on the public stage, whereby "a Clowne [might be] companion with a Kinge" (3) . ${ }^{12}$ For Thomas Nashe, in 1592, the occupation at "the idlest time of day " was playgoing alongside "gameing, following of harlots, drinking" (Apologie 25).. ${ }^{13}$ and Sir John Davies, in 1593, was both repelled and attracted by the crush of classes and types that tumbled out of theatres at play's end:

For as we see at all the play house dores,

When ended is the play, the daunce, and song,

A thousand townsmen, gentlemen, and whores,

Porters and serving-men together throng... (5-6)

It is difficult to find some universal sense in which a definition of spectating could be a consistent factor in assessing the most common responses, yet there is a drama here in the audience; the point is not really whether these descriptions follow certain ideological frames of reference, for they share a sense of liberation, be they welcome or not. For Dennis Kennedy, the way by which we might register any "gathered group" for drama is to understand "the gathering itself", both as it might be the result of convention but also as it is created - reached out to - in the performing (14). Thus, whilst we cannot achieve any probable sense of a unitary audience at this time, we can investigate the "audience-in-the head", that assumption as to how that "gathering" was addressed, not just in printed Prologues and Prefatory Epistles, but also within, and by, the action itself.

For Habermas, a cultural sense of "public" possibilities did not exclusively exist just in ideological possibilities as in the results of such motivation: "a [material] network for communication, information and points of view" (Between Facts and Norms 360). One could argue, therefore, that we would not now have to look far and wide to locate many and various perspectives and sites of information on "Shakespeare", but the vast majority of these are not quite what Habermas would have regarded as "in" the Public Sphere, but rather promoted and managed by special (often commercial) interests. How do we therefore decipher these less-thanwelcome influences?

\footnotetext{
12 Whetstone's main preoccupation is with observing due decorum in speech: "yea they vse one order of speach for all persons: a grose Indecorum, for a Crowe, wyll yll counterfet the Nightingales sweete voice: euen so, affected speeche doth misbecome a Clowne" (3).

${ }^{13}$ Nashe is, however, a supporter of plays as displaying divine justice: "In Playes, all cosonages, all cunning drifts ouer-guylded with outward holinesse, all stratagems of warre, all the cankerwormes that breede on the rust of peace, are most liuely anatomiz'd: they shew the ill successe of treason, the fall of hastie clim|bers, the wretched end of vsurpers, the miserie of ciuill dissention, and how iust God is euermore in punishing of murther" (Apologie 25).
} 
In Christopher B. Balme's The Theatrical Public Sphere (12-21), Habermas's terms and expectations are usefully adapted to analyses of audience experience, a potential complex of often unformulated emotions and instincts that pre-exist an actual performance, and are unlocked - in the most valuable instances - in a particular time and space. Thus, one focus in performance could be on how conventions of being an audience are referred to and transgressed or reinforced; another stresses the references to publicly available issues whereby the auditorium is a site of debate, and yet another concentrates on such public allusions derived from plot or narrative devices that may seem to attract just private understanding, through monologue or individual histories. There is a paradox here in that we cannot often conceive or credit models of audience involvement that are initially foreign to our own and yet this inevitable conservatism leaves us vulnerable to such radical redefinition; we may even deny the radical and feel uncomfortable in the process, and even state that we might not like it, yet it stays with and involves us. To return to Dennis Kennedy's investigation of theatrical spectacle, we have to accept that it is possible to deny that the play's the (only and preeminent) thing when assessing a dramatic event, for the early modern spectator "often attended the theatre without attending to the play" (12). In contemporary cultures, this realisation inverts a more traditional assumption that the ephemeral and localized effect - as written, devised or seen - is of a lesser impact than more universal comment on human conditions or transhistorical political concerns. Such dramatic art might intervene and take sides, and we might not - in the light of anticipated posterity - feel the validity of its qualities as we have perhaps been trained to.

Although one can take issue with some of Habermas's emphases, his researches remain valuable when attempting to register various cultures of expressive freedoms. What Habermas termed "communicative action", where there was located an authentic discussion - with little self-interested wrestling for material or reputational advantage - wedded to direct political and/or cultural results, was not just the mapping of individual creativity but also was derived from enabling social conditions (see Communicative Action). This has its material factors; for example, where were stages placed to enable the growth of a secular public theatre ? Were writers protected from legal redress, and - less investigated and so less acknowledged - how might we chart any ideological/mental capacity to imagine freely? Whereas there has been fruitful commentary on his sense of the "political" PS, regarded as residing in coffee-house culture or other non-aligned public spaces, there has been very little investigation into how he thought that the "cultural" PS might be constructed (his example was more modern literary salons, a relatively autonomous culture constructed out of experiences associated with "the reading room and the theatre, in museums and at concerts" (Structural 29). To apply this perception to London's early-modern theatre world involves an estimation of whether there might have been equivalent cultural experiences at that time and place. 
For several crucial studies of an Early Modern theatrical space (such as those by Janette Dillon, Jeffrey S. Doty, Alison Findlay, Jean Howard and Steven Mullaney) the growth of a self-conscious theatre audience on the one hand and the shifting boundaries of more general public/private practices on the other involves an analysis of often implicit deictic codes embedded in plot and staged gestures. To this degree, the deepest context for an Early Modern "publicity" lies in rich patterns of phrases and fertile word-choice, where the emergent and residual vie for attention.

An additional task of the theatre critic, or indeed any theatre-goer, is to grasp hold of what Alan Dessen has termed a "theatrical vocabulary", where we are to dare to interpret "without a dictionary", and where juxtapositions and verbal or gestural placement come to the fore (39-63), and where, in the most satisfying experiences, we feel we have entered into "the middle of a conversation" in a language that "we only partly understand"(5). It is only by looking beyond the text and lifting our eyes from the page, by reading and spectating with an eye for accretion and "doubling", in Iser's sense, that we can recover the full texture of any script designed for public performance. To take Iser's point about the doubling of meaning seriously entails a recognition of our gestalt intention to bridge difference, to throw a sort of rope bridge between words that appear similar in meaning, but that actually end up demonstrating the opposite: semes that are proposed rather than naturally occur in some mimetic clarity. To summarise Iser, it becomes no longer accurate to search for some prior signified, as the motive is not imitation but "performance ... a process of staging" that is endowed "with an intangible quality" (17). Consequently, whilst it is possible to find an end-point to plotting (the conventional fortunate or unfortunate arrangement of the fifth act), one might look in vain for this thematically, unless there is a clumsy and anti-climactic closing down of options, into which there lands a deus ex machina or, in an ironic vein, too perfect and ordered a disentanglement where one suspects that the world is not quite like that, and the intermediate complexities do not lead inexorably to such a manufactured punkt: an " unending oscillation by which closed positions are opened up again and apparent finalities are outstripped. To provide conditions for this state to be imagined, its staging must simultaneously deprive these conditions of any claim to authenticity" (247-48). Consequently, in a most marked way, certain of Shakespeare's works turn out to be problems, but that these are not exceptionally so and are only regarded as thus because their "staged" oscillations are more obvious than we might expect in a neat organic whole. Thus, what can seem contradictions are - when peered at more closely - "doublings" in Iser's sense: returns with interest, where we sense an ulterior complexity that surface statements or gestures hide or only imperfectly signal.

Now, at this moment, the opportunities for lively and informed re-interpretation need reinforcing; in this aspiration we might also appreciate a radical re-visioning of 
where any performance may now be located within a physical (and virtual) space commonly sensed by any audience as a community. Moreover, we might avoid too many concessions to the comparative safety of the study and the percentage games of heritage, that "generation that would like to stay in school", as David Mamet identifies:

The audience will teach you how to act and the audience will teach you how to write and direct. The classroom will teach you how to obey, and obedience in the theatre will get you nowhere. It's a soothing falsity (19).

I somehow get the impression that Shakespeare did not write in order to soothe.

\section{Works Cited}

Arendt, Hannah. Revolution. New York and London: Penguin. 1963.

Bacon, Francis. The Twoo Bookes of Francis Bacon. Of the proficence and advancement of Learning, divine and humane. London: printed by Thomas Purfoot and Thomas Creede for Henrie Tomes. 1605.

Balme, Christopher B. The Theatrical Public Sphere. Cambridge: Cambridge UP. 2014.

Bate, Jonathan. Shakespeare and Ovid. Oxford: Clarendon Press. 1993.

Bonnefoy, Yves. "Lifting Our Eyes From the Page". Trans, John Naughton, Critical Inquiry, 16:4 (1990): 794-806,

Butler, Judith. Notes Toward a Performative Theory of Assembly. Cambridge, Mass.: Harvard UP. 2015.

Clegg, Cyndia Susan. Shakespeare's Reading Audiences: Early Modern Books and Audience Interpretation. Cambridge: Cambridge UP. 2017.

C.M., for I.D. 1593. 
Dawson, Anthony B. and Paul Yachnin. Eds. The Culture of Playgoing in

Shakespeare's England: A Collaborative Debate. Cambridge: Cambridge UP 2001.

Dessen, Alan C. Recovering Shakespeare's Theatrical Vocabulary. Cambridge: Cambridge UP. 1995.

Dillon, Janette. Theatre, Court and City, 1595-1610: Drama and Social Space in London. Cambridge: Cambridge UP. 2000.

Donno, Elizabeth. Ed. Twelfth Night. Cambridge: Cambridge UP. 1985.

Doty, Jeffrey S. Shakespeare, Popularity and the Public Sphere. Cambridge:

Cambridge UP. 2017.

Elam, Keir. Ed. Twelfth Night. London: Bloomsbury. 2008.

Findlay, Alison. Playing Spaces in Early Women's Drama. Cambridge: Cambridge UP. 2006.

Gosson, Stephen. The Trumpet of Warre. London: printed by V.S. for I.O. 1610.

Greenblatt, Stephen. Shakespearean Negotiations: The Circulation of Social Energy in Renaissance England. Berkeley: Univ. of California Press. 1988.

Habermas, Jürgen. The Theory of Communicative Action. 2 vols. Trans. Thomas A. McCarthy. Boston: Beacon Press; 1st. pub.1981 as Theorie des Kommunikativen Handelns.1981. 1988

Habermas, Jürgen. The Structural Transformation of the Public Sphere: Inquiry into a Category of Bourgeois Society. Trans. Thomas Burger and Frederick Lawrence. Cambridge: Polity Press; 1st pub 1962 as Strukturwandel der Öffenlichkeit. 1962). 1992.

Habermas, Jürgen. Between Facts and Norms; Contributions to a Discourse Theory of Law and Democracy. Boston: MIT Press; 1st pub. 1992 as Fakizität und Geltung. 1996.

Holinshed,Raphael. "A Report to Hir Maiesties most gratious answer...", Chronicles of England, Scotland, and Ireland. London: J. Johnson, etc. 1587.

Howard, Jean. Theater of a City: The Places of London Comedy, 1598-1642.

Philadelphia: Univ of Pennsylvania Press. 2009

Iser, Wolfgang. Prospecting: from Reader Response to Literary Anthropology. Baltimore: Johns Hopkins Press. 1989.

James VII and I. "Basilicon Doron". King James VI and I: Political Writings. Ed. J.P.Somerville. Cambridge: Cambridge UP. 2010. 
Kastan, David Scott. Shakespeare After Theory. London and New York: Routledge. 1999.

Kennedy, Dennis. The Spectator and the Spectacle: Audiences in Modernity and Postmodernity. Cambridge: Cambridge UP. 2011.

Lake Peter and Steven Pincus. Eds. The Politics of the Public Sphere in Early Modern England. Manchester: Manchester UP. 2007.

Lothian, J.M. and T.W.Craik. Eds. Twelfth Night. London: Methuen. 1975.

Mamet, David. True and False: Heresy and Common Sense for the Actor. London: Faber and Faber. 1998.

Marlowe, Christopher. Doctor Faustus. Ed. Roma Gill; rev Ros King. London: Methuen Drama. 2008.

Marston, John. Histrio-mastix; or, the Player Whipt. London: G.Eld, for T.Thorp. 1610.

Maus, Katherine. Inwardness and Theater in the English Renaissance. Chicago: Univ. of Chicago Press. 1995.

Montrose, Louis. The Purpose of Playing: Shakespeare and the Cultural Politics of the Elizabethan Theatre. Chicago: Univ of Chicago Press. 1996.

Montrose, Louis. "Shakespeare, the Stage, and the State". SubStance 25 (1996): 4667.

Mullaney, Steven. The Place of the Stage: License, Play, and Power in Renaissance England. Ann Arbor: Univ.of Michigan Press. 1995.

Munro, Lucy, "Speaking History: Linguistic Memory and the Usable Past in the Early Modern History Play", HLQ 76:4 (2013): 519-40.

Munro, Lucy. Archaic Style in English Literature, 1590-1674. Cambridge: Cambridge UP. 2013.

Nashe, Thomas. The Apologie of Pierce Pennilesse: His Supplication to the Divell. London STC 18378. 1592.

Nashe, Thomas. A Pleasant Comedie, called Summer's Last Will and Testament. London: S. Stafford, for W.Burne. 1600.

Orlin, Lena Cowen. "Making Public the Private". Forms of Association: Making Publics in Early Modern Europe. Eds. Paul Yachnin and Marlene Eberhart. Amherst and Boston: Univ of Massachusetts Press. pp. 93-114. 2015.

Patterson, Annabel. Shakespeare and the Popular Voice. Oxford: Basil Blackwell. 1989. 
Reynolds, Paige Martin. "George Peele and the Judgement of Elizabeth I", SEL 50.2 (2010): 263-79.

Rudd, Niall. "Pyramus and Thisbe in Shakespeare and Ovid". Shakespeare's Ovid: The Metamorphoses in the Plays and Poems. Ed. A.B.Taylor. Cambridge: Cambridge UP. pp. 113-25. 2000.

Smith, Bruce R. Ed. Twelfth Night: Texts and Contexts. Boston and New York: Bedford/St Martins. 2001.

Stavig, Mark. The Forms of Things Unknown: Renaissance Metaphor in Romeo and Juliet and Midsummer Night's Dream. Pittsburgh, Penn.: Duquesne University Press. 1995.

Sweeney III, John Gordon. Jonson and the Psychology of Public Theater: "To Coin the Spirit, Spend the Soul". Princeton: Princeton UP. 1985.

Taylor, A.B.. Ed. Shakespeare's Ovid: The Metamorphoses in the Plays and Poems. Cambridge: Cambridge UP. 2000.

Warren, Roger and Stanley Wells. Eds. Twelfth Night. Oxford: Oxford UP. 1995.

Whetstone, George. "Prefatory Epistle". The Right Excellent Historye of Promos and Cassandra. London: R. Ihones. 1578.

Wilson, Richard. Worldly Shakespeare: The Theatre of Our Good Will. Edinburgh: Edinburgh UP. 2016.

White, R.S. "Metamorphosis by Love in Elizabethan Romance, Romantic Comedy, and Shakespeare's Early Comedies" RES n.s. (1984): 14-44

Wimsatt, W.K. and Monroe C. Beardsley. The Verbal Icon: Studies in the Meaning of Poetry. Lexington: University of Kentucky Press; 1st pub., 1954. 1990.

Yachnin, Paul and Marlene Eberhart. Ed. Forms of Association: Making Publics in Early Modern Europe. Amherst and Boston: Univ of Massachusetts Press. 2015. 